\section{Kjønnsrollenes seige strukturer}

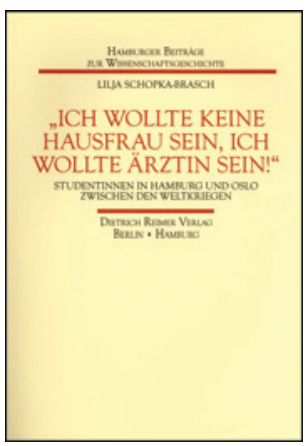

Lilja Schopka-Brasch

«Ich wollte keine Haufrau sein, ich wollte

\section{Ärztin sein!»}

Studentinnen in Hamburg und Oslo zwischen den Weltkriegen. 283 s, tab, ill. Berlin: Dietrich Reimer Verlag, 2012. Pris EUR 39

ISBN 978-3-496-02853-6
Vi har mye å takke våre formødre for. I dag er det mulig for kvinner å studere og velge en akademisk karriere, og vi blir i all hovedsak akseptert som fullverdige medlemmer av det akademiske samfunn. Det har ikke alltid vært sånn.

Den tyske historikeren Lilja Schopka-Brasch viser i sin doktoravhandling fra 2009 (bearbeidet utgave 2012) en annen virkelighet, uten å måtte gå så veldig mange tiår tilbake. Grundig og veldokumentert - på tysk vis - har hun undersøkt mellomkrigstidens kvinnelige akademikere i henholdsvis Hamburg og Oslo. Og hun spør: Brøt disse kvinnene med tidens kvinneideal? Hovedvekten er lagt på gifte, kvinnelige medisinere. Med grunnlag i et bredt anlagt kildemateriale, der intervjuer med 33 kvinner utgjør den viktigste kildegruppen, går hun inn på deres forutsetninger for å søke høyere utdanning, deres erfaringer som studenter i en svært mannsdominert universitetsverden, og deres erfaringer som yrkeskvinner med familieforpliktelser. Forfatterens fortjeneste er at hun konsentrerer seg om mellomkrigstidens akademikere, og ikke århundreskiftets pionerer - om dem foreligger det allerede tallrike studier.

Forfatteren redegjør for samtidens kjønnsrolleoppfatninger. Det var oppfatninger med rot i opplysningstiden, men som knapt nok hadde endret seg gjennom 1800- og første halvdel av 1900-tallet. Kjønnsordningen ble forklart ut fra naturen. På bakgrunn av biologiske forskjeller ble kjønnsmessige grunnkarakterer avledet, og kjønnenes oppgave- og ansvarsområder fastlagt. Mannen var skaffende, kvinnen bevarende. Mannens arena var det offentlige liv, kvinnens var hjemmet. Mannen ble tillagt karaktertrekk som aktiv, rasjonell, besluttsom og med gjennomføringsevne, kvinnen som passiv, emosjonell, yndig og mild. Det var et hierarkisk system preget av makt versus avmakt og dominans versus underordning.

Komparative undersøkelser mellom ulike land er krevende, men gir ofte fruktbar innsikt og overraskende funn. Slik også med Schopka-Braschs studie. Vi er mange som har hatt en forestilling om at Norge var forholdsvis sent ute med å innvilge kvinner adgang til høyere utdanning, men bildet er mer nyansert enn som så. Norske kvinner fikk adgang til å studere i 1884, mens i Tyskland måtte de vente til begynnelsen av det neste hundreåret. I Norge fikk kvinner ta artium fra 1880-årene, mens i Hamburg ble det først i 1910 etablert offentlige høyere skoler for jenter. I Preussen var det i 1920 bare $7 \%$ kvinner som tok artium (Abitur), i Norge rundt $25 \%$. Norske kvinner fikk adgang til embetsstillinger i 1912, tyske i 1919. Til tross for denne usamtidigheten i fremveksten av kvinners rettigheter, hadde forfatteren som tese at det $\mathrm{i}$ begge land var sammenfallende kjønnsspesifikke rolleforståelser, og at dette førte til like grunnmønstre i norske og tyske kvinners livsløp. Tesen ble til dels bekreftet.

Hva innebar så dette grunnmønsteret i relasjon til skoletid, studietid og yrkeskarriere? Samtlige informanter hadde en borgerlig bakgrunn. I de borgerlige miljøene var kjønnsrollemønsteret formidlet gjennom generasjoner, og jentene lærte tidlig å stille egne behov i bakgrunnen for de mannlige familiemedlemmenes. Som skolejenter skilte de fremtidige akademikerkvinnene seg ut. De var fremfor alt vitebegjærlige og opptatt av å prestere. De fleste valgte likevel de «lettere» språklinjene og ikke latin og de «vanskelige» naturfagene. Slik slo kjønnsrolleforventningene inn også for disse kvinnene, forventninger som må ha hindret mange fra å realisere ønsker og drømmer.

Informantene oppga at de ikke opplevde åpen diskriminering i studietiden, men at de absolutt ble oppfattet som et «akademikerproletariat». I Tyskland innførte nasjonalsosialistene adgangsbegrensning til universitetene for kvinner fra våren 1933. Det var problematisk å få stipend, og ikke-ariere og «politisk upålitelige» lærere og studenter, av begge kjønn, ble drevet ut. I Hamburg ble en femdel av universitetslærerne offer for denne politikken. Disse gruppene mistet også mulighetene til å praktisere som leger, blant disse en tredel av Hamburgs kvinnelige leger. For de øvrige medisinstudentene og legene førte ikke den nye politikken til vesentlige endringer, men selve medisinstudiet forandret seg. Rasehygiene ble eksamensfag, og studentene fikk plikter som ikke hadde noe med selve studiet å gjøre - som politisk fagforeningsarbeid og en særskilt kvinnetjeneste. Dette sto i motsetning til i Norge der alle forsøk på å nazifisere universitetet ble slått tilbake. På grunn av motstandsaktiviteter ble universitetet stengt i 1943, og mange måtte utsette så vel studier som yrkesliv.

Tyske kvinnelige leger kunne ikke praktisere for sykekassen, ulikt sine norske kolleger. Dette innebar et innskrenket arbeidsmarked. I begge landene finner vi graverende forskjeller i hvordan kvinner og menn formet sine yrkeskarrierer. De fleste kvinnene satset på privatpraksis uten videre karriere, mennene det motsatte. Kvinner som spesialiserte seg, valgte typiske «kvinnefag» som dermatologi, psykiatri, barnesykdommer og gynekologi - fag med lavere sosial prestisje og dårligere inntjeningsmuligheter. I begge land stilte de seg i skyggen av sine menn og støttet dem i deres karrierer. Egne yrkesambisjoner kom i annen rekke. Slik tilpasset de seg rolleforventningene og var fleksible mellom ulike rollesystemer - som hustru og mor på den ene siden, som yrkeskvinne på den andre.

Disse kvinnene oppfattet ikke seg selv som uvanlige, skriver Schopka-Brasch, selv om de absolutt var det. De gikk opp veier og utviklet strategier som gjorde det mulig å kombinere familiære og yrkesmessige forpliktelser. Dermed ble de også foregangskvinner. Men kanskje la de opp til en vel ambisiøs kvinnerolle for oss som er kommet etter, og som skal kombinere så vel mannens som kvinnens «typiske» karaktertrekk? Boken er uansett interessant og gir nyttig innsikt i en hittil ukjent side ved legeprofesjonens fremvekst.

\section{Aina Schiøtz}

Institutt for global helse og samfunnsmedisin Universitetet i Bergen 